en method required improvement of a quality of applied metal clamps in order to increase their strength properties, as well as technical support the possibility of their modeling during the operation.

\title{
References:
}

1. Krivchenia D.Yu. et al. Variants of modifications the Nuss operation in a correction of the funnel chest deformation: advantages and disadvantages, Surgery of children's age, 2011, 1: 27-30.

2. Malakhov OA, Zherdev KV, Chelpachenko OB. Orthopedic aspects and features of surgical treatment of the funnel chest deformation in the children and adolescents, Bulletin of traumatology and orthopedics, named by N.N. Priorova, 2011, 3: 3-9.

3. Plyakin VA, Kulik IO, Sarukhanyan OO. Comparative assessment of the operations by Nuss and Ravich for treatment of the funnel chest deformation, Pediatric surgery, 2013, 3: 60-64.

4. D. Nuss, R.E. Kelly Jr., D.P. Croitoru, M.E. Katz. A 10-year review of a minimally invasive technique for the correction of pectus excavatum, J. Pediatr. Surg., 1998, Vol. 33 (4): 545-552.

5. Petersen C. Funnel chest. New aspects since introduction of a minimally invasive surgical technique, Orthopade. 2003 Oct;32(10):916-9.

6. Kelly RE Jr. Pectus excavatum: historical background, clinical picture, preoperative evaluation and criteria for operation, Semin Pediatr Surg. 2008 Aug;17(3):181-93.

DOI https://doi.org/10.30525/978-9934-588-81-5-1.27

\section{INFLUENCE OF ANDROGEN DEFICIENCY ON THE FORMATION OF DISORDERS OF THE CARDIOVASCULAR SYSTEM DURING PUBERTY, TAKING INTO ACCOUNT CHANGES IN OXIDATIVE BALANCE}

\author{
Kashkalda D. A. \\ PhD, Senior Researcher, \\ Leading Researcher at the Laboratory \\ of Age-related Endocrinology and Metabolism \\ Institute for Children and Adolescents Health Care \\ of the National Academy of Medical Sciences of Ukraine
}




\section{Volkova Yu. V.}

PhD,

\section{Head of laboratory of Age-related Endocrinology and Metabolism}

Institute for Children and Adolescents Health Care

of the National Academy of Medical Sciences of Ukraine

\section{Sukhova L. L.}

$P h D$,

Researcher at the Laboratory of Age-related Endocrinology and Metabolism

Institute for Children and Adolescents Health Care

of the National Academy of Medical Sciences of Ukraine

Sharun K. V.

Research Assistant at the Laboratory

of Age-related Endocrinology and Metabolism,

Institute for Children and Adolescents Health Care

of the National Academy of Medical Sciences of Ukraine

Kosovtsova H. V.

$P h D$,

Senior Researcher at the Department of Endocrinology,

Institute for Children and Adolescents Health Care

of the National Academy of Medical Sciences of Ukraine

Kharkiv, Ukraine

Disorders of metabolic processes in the male body are closely interrelated with androgen deficiency, which is one of the mechanisms of the onset and progression of pathological conditions, in particular, the cardiovascular system (CVS) [1]. The relationship between testosterone level and the state of oxidative stress has been proven [2]. According to the literature, the role of free radical oxidation (FRO) and antioxidant defense (AOD) processes in the onset and development of CVS diseases in children has been established [3].

However, studies of the influence of androgen deficiency on the state of the FRO and AOD processes in CVS disorders were carried out under experimental conditions on animals or concern mainly adult men.

In this regard, the purpose of this study is to investigate the effect of hypoandrogenism (HA) in adolescents on the indicators of oxidative balance in violation of the functional state of the CVS.

Materials and methods. The study included 57 adolescents aged 13-18 years with HA and functional disorders of the CVS. The state of CVS was assessed using functional indices: endurance coefficient (EC) and 
blood circulation efficiency coefficient (BCEC). An increase in EC over 20 c.u. was considered a weakening, and a decrease less than 16 c.u. - an increasing the functionality of the CVS. Increase of BCEC over 2600 c.u. testified to the savings in the expenditure of CVS reserves, that is, to the decrease in the body's energy consumption for blood circulation in case of fatigue.

The state of FRO was judged by the level of TBA-active products (TBA), diene conjugates (DC), and carbonylated proteins (CP) in the blood serum. The AOD system was assessed by the content of reduced glutathione (GSH) and the activity of glutathione peroxidase (GPx) in whole blood, the activity of superoxide dismutase (SOD) and catalase in the blood serum.

Statistical processing of the results was carried out using the "Statgraphics Plus 5.1» software package. To assess the significance of differences, the Mann-Whitney (u) test and the Fisher $F$-test $(\varphi)$ were used.

Results and discussion

Evaluating the state of the CVS using the EC and BCEC indices, we identified functional disorders in more than half of adolescents with androgen deficiency (62.7\%). Analyzing the changes in FRO and AOD indices in boys with HA at different EC values, an increase in the concentration of $\mathrm{DC}$ and $\mathrm{CP}$ in blood serum was found to a greater extent with a weakening of the functional capabilities of the CVS (EC is more than 20 c.u.).

At the same time, the content of DC increased by $43.3 \%$ compared to the normal functional state of the CVS and amounted to $0.66 \pm 0.06 \mathrm{nmol} / \mathrm{L}$, respectively, in contrast to $0.46 \pm 0.06 \mathrm{nmol} / \mathrm{L}\left(\mathrm{p}_{\mathrm{u}}<0.05\right.$ ), and the CP level increased 1.6 times and corresponded to $1.33 \pm 0.12 \mathrm{U} / \mathrm{ml}$ compared to $0.88 \pm 0.10 \mathrm{U} / \mathrm{ml}$, respectively $\left(\mathrm{p}_{\mathrm{u}}<0.01\right)$. Moreover, in adolescents with HA, with weakening of the functional capabilities of the CVS, high CP values were reliably more frequent than with its satisfactory state $(76.9 \%$ and $35.3 \%$, respectively; $\left.\mathrm{p}_{\varphi}<0.005\right)$.

Simultaneously with the intensification of the FRO processes in boys with androgen deficiency against the background of a decrease in the functional capabilities of the CVS, an increase (by $26.9 \%$ ) in SOD activity was recorded from $1.33 \pm 0.10 \mathrm{U} / \mathrm{min} \bullet \mathrm{ml}$ to $1.65 \pm 0.06 \mathrm{U} / \mathrm{min} \bullet \mathrm{ml}\left(\mathrm{p}_{\mathrm{u}}<0.04\right)$. At the same time, a high level of the enzyme was observed in them 2 times more often $\left(61.5 \%\right.$ and $\left.29.4 \% ; \mathrm{p}_{\varphi}<0.03\right)$. SOD belongs to the enzymes of the initial stage of FRO, deactivates the superoxide radical, converting it to less reactive hydrogen peroxide.

In parallel with the activation of the AOD enzymatic link, an increase (by $33.3 \%)$ in the content of GSH in whole blood was noted $(0.48 \pm 0.06$ 
$\mu \mathrm{mol} / \mathrm{L}$ and $0.36 \pm 0.07 \mu \mathrm{mol} / \mathrm{L}$, respectively; $\left.\mathrm{p}_{\mathrm{u}}<0.04\right)$. Moreover, a high concentration of the antioxidant was found in $76.9 \%$ of patients, which evidently indicates a compensatory reaction of one of the main lowmolecular antioxidants, aimed at neutralizing the toxic products of FRO.

With a decrease in the body's energy consumption for blood circulation (the average values of the BCEC were $3636.58 \pm 171.78$ c.u.), in comparison with the normal work of the heart, inhibition of the activity of anti-peroxide protection enzymes was observed, in particular, GPx $(7.37 \pm 0.48 \mu \mathrm{mol} / \mathrm{min} \bullet \mathrm{ml}$ and $9.05 \pm 0.78 \mu \mathrm{mol} / \mathrm{min} \bullet \mathrm{ml}$, respectively; $\left.\mathrm{p}_{\mathrm{u}}<0.06\right) \quad$ and catalase $\quad(17.07 \pm 1.87 \mu \mathrm{mol} / \mathrm{min} \bullet \mathrm{ml} \quad$ and $\left.23.86 \pm 3.62 \mu \mathrm{mol} / \mathrm{min} \cdot \mathrm{ml} ; \mathrm{p}_{\mathrm{u}}<0.05\right)$. It draws attention to the fact that boys with reduced CVS reserve capabilities are 1.5 times less likely to have high rates of SOD activity (37.4\% and $\left.57.9 \% ; \mathrm{p}_{\varphi}<0.05\right)$.

Conclusions. Thus, in adolescents with HA and functional disorders of the CVS, stimulation of FRO processes and inhibition of the AOD system are recorded. The imbalance in the ratio of these processes is more pronounced with the weakening of the functional capabilities of the heart. The detected changes indicate functional tension of the CVS and a decrease in the adaptive reactions of the boys' body with androgen deficiency.

Excessive formation of highly toxic products of FRO (DC and CP) under conditions of inhibition of the activity of antioxidant enzymes (GPx, catalase) can cause disruption of the structure and function of cell membranes of cardiocytes and the development of chronic CVS diseases.

To date, $15.4 \%$ of boys with HA have some sort of CVS pathology (cardiopathy, mitral valve prolapse, etc.), which must be taken into account when treating this contingent of adolescents.

\section{References:}

1. Tostes R. C., Carneiro F. S., Carvalho M. H., Reckelhoff J. F. Reactive oxygen species: players in the cardiovascular effects of testosterone. Am J Physiol Regul Integr Comp Physiol. 2016. № 310. P. 1-14.

2. Banihani S. A. Effect of coenzyme Q10 supplementation on testosterone. Biomolecules. 2018. N. 8 (4). P. 172-181.

3. Колесникова Л. И., Прохорова Ж. В., Власов Б. Я., Поляков В. М. Редокс-статус как метаболическое звено, интегрирующее эмоциональный паттерн подростка и его артериальное давление. Бюллетень экспериментальной биологии и медицины. 2014. № 158 (7). C. $12-15$. 